forward earlier by Eliassen himself, and by J. S. Sawyer in the United Kingdom. The same mechanism seems likely to account for the eye of the tropical cyclone.

Finally, one should mention a stimulating essay by Bergeron on the history of ideas in weather analysis and forecasting, with hints on their further development. The author is admittedly depressed by much of the story, of promising lines forsaken and sterile paths pursued, and he finds a major ill in the want of meteorological knowledge of theoreticians (Helm. holtz is his first example) and a too-poor mathematical training of 'weather men'. The subject, he says, needs a Maxwell-Hertz in one person and the nearest approximation to have appeared so far was $V$. and $J$. Bjerknes, father and son. He pleads for a Lagrangian rather than an Eulerian approach to weather analysis, instancing the success of the Bergen frontal school and of Rossby's Chicago school in this respect, but he recognizes that Lagrangian techniques have not yet been well developed. Perhaps the study of the evolution of the atmosphere will never become an exact science, though the limits of climatic variation. suggest that, appropriately formulated, the problem should be soluble. Even in its present formulation there is ample scope for development and Bergeron helps to point the way.

This is a volume of which, one can be sure, Rossby would be proud, a fine example of the growth and stature of the sciences with which it deals and which Rossby spent himself in building. P. A. Sheppard

\section{PLANT GEOGRAPHY}

\section{Introduction to Plant Geography and Some Related} Sciences

By Prof. Nicholas Polunin. Pp. xix +640 . (London : Longmans, Green and Co., Ltd., 1960.) 60s. net.

T THIS volume is intended to provide "an intro. duction not only to Plant Geography in the wide sense, but also to much of Plant Ecology and Sociology, to the Plant Kingdom as a whole, and to Economic Botany". Such a task has obvious difficulties, and the subjects make a strange mixture for what is presumably meant to be essentially an introductory text-book on plant geography.

After a preliminary chapter, there follow several dealing with plant classification, physiological reactions, 'adaptations', life-forms, dispersal and migration, and fossil plants. Two chapters deal with foundations of modern distribution and with types and areas of natural distributions. There are then interpolated matters under the headings "Modification and Distribution of Crops (and Weeds)" and "Vital Importance to Mankind". There follow a summary account of environmental factors and an outline of main habitats, successions, and climaxes. Not until more than half-way through the book are the 'vegetational types' dealt with. These are subdivided into those of temperate and adjacent lands, of polar lands and high altitudes, of tropical and adjacent lands, of fresh and inland saline waters, and of seas. The book ends with two chapters entitled "Landscapes and Vegetation" and "Plant Adjustments and Applications", respectively. A great deal of space is occupied by material not immediately relevant to plant geography. As one consequence of this, many of the important phytogeographical subdivisions of the world are very inadequately con- sidered. Another criticism concerns the sequence of the chapters. Thus, polar lands are dealt with between those with temperate and those with tropical climates.

On the other hand, it must be fairly stated that on the whole the descriptive statements are accurate so far as they go. Controversial matters, such as transoceanic dispersal, continental drift, and nunataks are outlined with the various points of view given without bias. The account of the vegetation of polar lands is a good résumé; but other areas, such as the Mediterranean region, are inadequately treated. The inclusion of a chapter on marine vegetation is commendable.

The fount and format are excellent, and there is a good index. A coloured map has the caption "Generalized Land Vegetation Map of the World" and was prepared by A. W. Küchler (1958) with northern forest and arctic limits by $\mathbf{N}$. Polunin. This map is in parts difficult to interpret and appears to have little connexion with the text. There are 184 figures, the majority from photographs, and many of these are clear and relevant to the text. Bibliographical references are given at the ends of chapters. but these are mostly to books and not to original papers.

W. B. Turrill

\section{A TRILOGY OF VIROLOGY}

\section{The Viruses}

Biochemical, Biological, and Biophysical Propertie:: Edited by F. M. Bumet and W. M. Stanley. Vol. 1 : General Virology. Pp. xvii +609. 16.50 dollars; 118s. Vol. 2 : Plant and Bacterial Viruses. Pp. xvi +408 . 13 dollars. Vol. 3 : Animal Viruses. Pp. xvii +428 . 12 dollars. (New York : Academic Press, Inc.; London: Academic Press, Ine. (London), Ltd., 1959.)

VIRUS research originated in pathology, and for more than half the nearly 70 years during which the existence of viruses has been recognized their study was an activity almost confined to pathologists, but the 34 articles that make up these three volumes carry few signs of this. The sub-title, "Biochemical, Biological and Biophysical Properties", makes it obvious that this would be no place to seek such mundane things as clinical descriptions or methods of controlling virus diseases, but it is unexpected that pathogenicity should be so neglected; no article is devoted specifically to it and fewer than 1 per cent of the nearly 1,500 pages even mention it. Yet pathogenicity is not only what makes viruses economically important, but is also the feature that usually first brings their existence to notice and that provides the means for their detection and assay in most kinds of work. If their biochemical and biological properties do not determine the many and varied ways in which viruses interfere with the normal functioning of host cells, what does ? It is true that the ability to infect and multiply, rather than to cause disease, is the prime feature of a virus and the one with the greatest significance to biology in general ; the emphasis given to this feature is therefore understandable, but it does not justify excluding other abilities rich in scientific interest and unsolved problems. Indeed, the replica. tion of nucleic acid and its relation to protein synthesis already looms so large in virus research that such exclusions can only lead to the subject becoming increasingly unbalanced by attracting a still greater 